\title{
Storage Humidity Influences Fruit Quality and Permeability to Ethane in 'McIntosh' Apples Stored in Diverse Controlled Atmospheres
}

\author{
P.D. Lidster \\ Agriculture Canada, Research Station, Kentville, N. S., B4N 1J5, Canada \\ Additional index words. Malus domestica, firmness, titratable acids, senescent disorders, low-oxygen injury, weight loss

\begin{abstract}
Storage of 'McIntosh' apples (Malus domestica Borkh.) in high humidity (94\% to $100 \%$ RH) or in $0.5 \%$ $\mathrm{CO}_{2}$ plus $1.0 \% \mathrm{O}_{2}$ at $3 \mathrm{C}(\mathrm{LO})$ atmospheres decreased resistance to ethane diffusion relative to fruit stored in low humidity $(75 \% \mathrm{RH})$ or in $5.0 \% \mathrm{CO}_{2}$ plus $3.0 \% \mathrm{O}_{2}$ at $3 \mathrm{C}(\mathrm{SCA})$, respectively. Loss of fruit firmness of SCA- or LOstored 'McIntosh' apples, determined immediately after storage or after 7 days at $20 \mathrm{C}$, decreased with increased storage humidity in each of three crop years. Storage humidity did not significantly affect $(P=0.05)$ fruit titratable acids or soluble solids contents. High storage humidity $(96 \%$ to $100 \% \mathrm{RH})$ generally increased the incidence of senescent disorders (consisting of senescent breakdown and senile brown core) in SCA-stored fruit, while humidities of $92 \%$ to $100 \% \mathrm{RH}$ decreased the incidence of low- $\mathrm{O}_{2}$ injuries (epidermal bluing and cortical browning) in LOstored fruit. Senescent disorders were found in SCA-stored fruit, but not in LO-stored fruit. The incidence of decay was not significantly affected by either storage humidity or atmosphere.
\end{abstract}

High storage humidity (RH) has been shown to predispose 'Cox's Orange Pippin', 'Bramley's Seedling', 'Delicious', and 'McIntosh' apples to senescent and/or low-temperature breakdown in air storage (Blanpied, 1981; Johnson, 1976; Rasmussen, 1963; Wilkinson, 1970). Breakdown of 'Jonathan' (Martin et al., 1967; Scott et al., 1964; Scott and Roberts, 1967) and 'Spartan' (Porritt and Meheriuk, 1973) fruit stored in air are similarly aggravated by high RH storage. Conversely, the reduction of storage RH by delays in storage temperature reduction (Scott and Roberts, 1968; Trout et al., 1940) or by raising the storage temperature to increase weight loss from the fruit (Smith, 1958) reduces the incidence of these disorders. Scott and Roberts (1968) report that a $1 \%$ increase in weight loss in response to low RH lowers the incidence of 'Jonathan' breakdown; they recommend a $4 \%$ weight loss for controlling breakdown without noticeable fruit shriveling.

'McIntosh' apples stored at 0 to $1 \mathrm{C}$ were found to be firmer when stored in air at high RH than similar apples (with greater weight loss) stored at low RH (Blanpied, 1981). The reason for lower firmness retention for apples stored in lower RH has not been reported, but may be, in part, due to advanced senility.

The incidence of low- $\mathrm{O}_{2}$ injury in 'McIntosh' apples stored in CA has been shown to result from exposure to low- $\mathrm{O}_{2}$ levels and the duration of exposure to these levels (Lau et al., 1987; Lidster et al., 1987). Internal $\mathrm{O}_{2}$ concentrations maybe affected by changes in fruit permeability resulting from storage $\mathrm{RH}$ (Wilkinson, 1965), which, in turn, may affect fruit susceptibility to low- $\mathrm{O}_{2}$ injury.

While the literature contains studies on the effects of humidity on apples stored in air, similar studies in controlled atmosphere storage were not found. The present study investigated the effects of storage RH on the retention of fruit firmness, titratable acids, soluble solids concentration (SSC), and on the incidence of storage disorders in 'McIntosh' apples stored in controlled

Received for publication 19 May 1987. Contribution no. 1898. Agriculture Canada, Research Station, Kentville, N.S. I gratefully acknowledge the technical assistance of H.J. Lightfoot and P.A. Harrison and the statistical assistance of K.B. McRae. The cost of publishing this paper was defrayed in part by the payment of page charges. Under postal regulations, this paper therefore must be hereby marked advertisement solely to indicate this fact. and in low- $\mathrm{O}_{2}$ atmospheres. In addition, the effects of storage RH and atmospheres on fruit permeability to ethane exchange were investigated, the latter serving as a tool to follow permeability changes.

\section{Materials and Methods}

Preclimacteric 'McIntosh' apples were harvested from each of five orchards on 25 Sept. 1983, 21 Sept. 1984, and 23 Sept. 1985 at mean starch indices/internal $\mathrm{C}_{2} \mathrm{H}_{4}\left(\mu \mathrm{l} \cdot \mathrm{kg}^{-1} \cdot \mathrm{hr}^{-1}\right)$ levels of 3.8/0.86, 3.9/0.34, and 3.6/0.32 and were precooled to $3 \mathrm{C}$ within $12 \mathrm{hr}$ of harvest in vented plastic hampers that were randomly placed in each of 10 controlled atmosphere chambers maintained at $3 \mathrm{C}$. In duplicate chambers, trays with a saturated solution of reagent grade $\mathrm{NaCl},\left(\mathrm{NH}_{4}\right)_{2} \mathrm{SO}_{4}$, or KCI were placed on top of the fruit within the chamber to maintain storage $\mathrm{RH}$ of $75 \%, 81 \%$, and $89 \% \mathrm{RH}$, respectively (Rockland, 1960). Two chambers received empty trays (equilibrium humidity), while the other two received trays of distilled $\mathrm{H}_{2} \mathrm{O}$ to maintain $\mathrm{RH}$ of $92 \%$ to $96 \%$ and $96 \%$ to $100 \%$, respectively. A blade fan was attached to each tray to circulate air over the tray and within the chamber at a maximum velocity of $16.5 \mathrm{~m} \cdot \mathrm{min}^{-1}$. In each of the three crop years, chambers were sealed and flushed with compressed $\mathrm{N}_{2}$ to reduce $\mathrm{O}_{2}$ levels to either $1 \%$ or $3 \% \mathrm{O}_{2}$ within 2, 3, and 5 days of harvest in 1983, 1984, and 1985, respectively. Levels of $\mathrm{CO}_{2}$ were maintained by $\mathrm{Ca}(\mathrm{OH})_{2}$ scrubbing and of $\mathrm{O}_{2}$ by controlled venting to ambient atmospheres. Fruit were stored at $0.5 \% \mathrm{CO}_{2}$ plus $1.0 \% \mathrm{O}_{2}(\mathrm{LO})$ or $5.0 \% \mathrm{CO}_{2}$ plus $3.0 \% \mathrm{O}_{2}(\mathrm{SCA})$ at $3 \mathrm{C}$ in each of five chambers for 198,225 , and 255 days in the three crop years, respectively. In 1984 and 1985 trials, the preweighed fruit and trays were reweighed after chamber opening and the net water loss recorded.

Fruit firmness was determined on a 10-fruit subsample from each orchard/treatment using a Ballauf penetrometer (opposite sectors tested with an 11.1-mm tip on peeled flesh) immediately after storage and after an additional 7 days at 20C. Titratable acids were determined by titrating a $2-\mathrm{ml}$ juice sample with $0.1 \mathrm{~N}$ $\mathrm{NaOH}$ ( $\mathrm{pH} 8.1$ endpoint), and SSC was determined on juice with a hand-held refractometer. In 1985, resistance of whole fruits to ethane transfer was determined by the method of Cameron and Yang (1982) for each orchard/treatment on 10 indi- 
Table 1. Effects of humidity, SCA, and LO atmospheres on weight loss and fruit permeability to ethane in 'McIntosh' apples stored at $3 C^{z}$.

\begin{tabular}{|c|c|c|c|c|c|c|}
\hline \multirow{3}{*}{$\begin{array}{c}\text { Storage } \\
\text { humidity } \\
(\%) \\
\end{array}$} & \multicolumn{4}{|c|}{$\begin{array}{c}\text { Fruit wt } \\
\operatorname{loss}^{\mathrm{y}}(\%, w / w)\end{array}$} & \multicolumn{2}{|c|}{$\begin{array}{c}\text { Fruit } \\
\text { resistance } \\
\text { to ethane } \\
\left(\log _{10} \mathrm{~s}^{\left.-\mathrm{cm}^{-1}\right)}\right.\end{array}$} \\
\hline & \multicolumn{2}{|c|}{1984} & \multicolumn{2}{|c|}{1985} & \multirow[b]{2}{*}{ SCA } & \multirow[b]{2}{*}{ LO } \\
\hline & $\widehat{\mathrm{SCA}}$ & $\overline{\mathrm{LO}}$ & $\widehat{\mathrm{SCA}}$ & $\mathrm{LO}$ & & \\
\hline 75 & 4.4 & 4.0 & 10.7 & 4.1 & -3.19 & -3.27 \\
\hline 81 & 2.7 & 3.4 & 3.7 & 3.0 & -3.49 & -3.51 \\
\hline 89 & 2.5 & 2.7 & 2.5 & 2.3 & -3.67 & -3.71 \\
\hline $92-96$ & 1.0 & 1.1 & 2.1 & 2.0 & -3.77 & -3.74 \\
\hline $96-100$ & 0.3 & 0.6 & 1.9 & 1.5 & -3.71 & -3.82 \\
\hline Mean & & & & & -3.57 & -3.61 \\
\hline \multicolumn{5}{|c|}{$\operatorname{SEM}(\mathrm{n}=5)$} & \multicolumn{2}{|c|}{0.012} \\
\hline \multicolumn{5}{|c|}{$\operatorname{SEM}(n=2)$} & \multicolumn{2}{|c|}{0.019} \\
\hline \multicolumn{5}{|c|}{ Significant effects $(P<0.05)$} & \multicolumn{2}{|c|}{$\mathrm{A}, \mathrm{H}$} \\
\hline
\end{tabular}

${ }^{2} \mathrm{SCA}=5 \% \mathrm{CO}_{2}+3 \% \mathrm{O}_{2} ; \mathrm{LO}=0.5 \% \mathrm{CO}_{2}+1.0 \% \mathrm{O}_{2}$.

${ }^{y}$ Determined from total weight loss of five-orchard replicates.

${ }^{x_{A}}=$ atmosphere, $\mathrm{H}=$ humidity.

vidual fruit taken from storage and equilibrated at 20C for 20 hr.

The incidence of disorders was determined on a 50-fruit subsample held at 20C for 7 days before examination. The disorders were classified either as senescent or low- $\mathrm{O}_{2}$ disorders according to the descriptions of Smock (1977).

Data, except fruit weight loss, were tested by analyses of variance; the means and SE are presented in Tables 1-3. Polynomial regression components or orthogonal contrasts were calculated to test for significant trends of storage humidity $(P=$ $0.05)$. Adequacy of the chosen model was assessed by an F test, which compared the fitted deviations with the residual mean square.

\section{Results and Discussion}

Fruit weight loss decreased with increased storage humidity in both years (Table 1). Fruit lost weight in all storage humid- ities and was associated with weight gain by the saturated salt solutions placed in the individual CA chambers (data not presented) or with condensation on the chamber walls $(96 \%$ to $100 \% \mathrm{RH})$. When RH was allowed to equilibrate under ambient atmosphere in chambers (92\% to $96 \% \mathrm{RH}$ ), fruit lost $1 \%$ to $2.1 \%$ of their weight and, when distilled $\mathrm{H}_{2} \mathrm{O}$ was stored in the chambers (96\% to $100 \% \mathrm{RH})$, fruit lost slightly less. Water uptake by fruit stored at high RH (Wilkinson, 1965) was absent.

The weight losses for 'McIntosh' apples (Table 1) stored at 3C $(0.3 \%$ to $10.7 \%$, w/w) were much lower than the expected values calculated by Wilkinson (1965) for 'Cox's Orange Pippin' apples. He developed weight loss estimates of $0.6 \%$ and $0.25 \%(\mathrm{w} / \mathrm{w})$ per week for apples stored at $3 \mathrm{C}$ in $80 \%$ and $90 \%$ $\mathrm{RH}$, respectively. For the crop years of 1984 and 1985, fruit weight losses were about one-fifth to one-half of those calculated by Wilkinson, indicating a cultivar difference or increased fruit resistance to water loss with extended storage (Lentz and Rooke, 1964).

Fruit gas resistance after storage (determined by the ethane diffusion method) generally decreased in response to increasing storage $\mathrm{RH}$ and to reduction in storage $\mathrm{CO}_{2}$ and $\mathrm{O}_{2}$ concentrations (Table 1). An increase in permeability of apples stored in high RH was observed by Wilkinson (1965), who attributed it to an increase in fruit volume. Wilkinson (1965) further speculated that greater fruit permeability may have resulted from increased skin orifice size or increased internal air spaces resulting from a rounding of cortical cells.

Higher storage $\mathrm{RH}$ was associated with greater fruit firmness retention immediately after storage and after 7 days at $20 \mathrm{C}$ in both storage atmospheres, except after 7 days of shelf life in 1985 (individual year data not presented). These results contrast with those reported for 'Spartan' (Porritt et al., 1973), but are similar to those of Blanpied (1981) for 'McIntosh'.

Titratable acids and SSC determined after storage or after 7 days at 20C were not significantly affected by RH (Table 2).

High RH increased the incidence of senescent disorders (senile brown core, senescent breakdown) in fruit stored in SCA (Table 3); results similar to those reported for 'McIntosh' and other cultivars stored in air at 0C (Blanpied, 1981; Johnson, 1976; Martin et al., 1967; Porritt and Meheriuk, 1973; Rasmussen, 1963; Scott et al., 1964; Scott and Roberts, 1967). For

Table 2. Effects of humidity, SCA, and LO atmospheres on fruit firmness, titratable acids, and soluble solids contents of 'McIntosh' apples stored at 3C over three crop years".

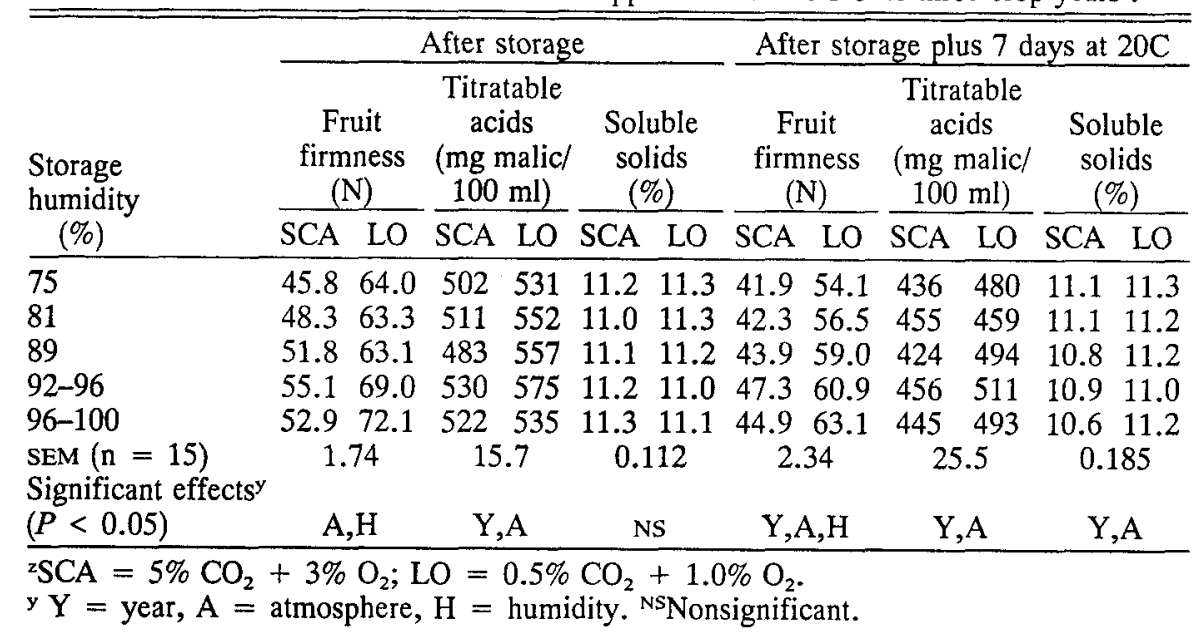


Table 3. Effects of humidity in SCA and LO atmospheres on the incidence of senescent disorders (senile brown core and senescent breakdown), low- $\mathrm{O}_{2}$ injury (epidermal bluing and cortical browing) and decay of 'McIntosh' apples after storage at $3 \mathrm{C}$ plus 7 days at $20 \mathrm{C}$, replicated over three crop years.

\begin{tabular}{|c|c|c|c|c|c|c|}
\hline \multirow[b]{3}{*}{$\begin{array}{l}\text { Storage } \\
\text { humidity } \\
(\%)\end{array}$} & \multicolumn{6}{|c|}{ Storage atmosphere $z$} \\
\hline & \multicolumn{3}{|c|}{$\mathrm{SCA}$} & \multicolumn{3}{|c|}{ LO } \\
\hline & $\begin{array}{c}\text { Senile } \\
\text { brown } \\
\text { core } \\
(\%) \\
\end{array}$ & $\begin{array}{c}\text { Senescent } \\
\text { breakdown } \\
(\%)\end{array}$ & $\begin{array}{c}\text { Decay } \\
(\%)\end{array}$ & $\begin{array}{c}\text { Epidermal } \\
\text { bluing } \\
(\%)\end{array}$ & $\begin{array}{c}\text { Cortical } \\
\text { browning } \\
(\%)\end{array}$ & $\begin{array}{c}\text { Decay } \\
(\%)\end{array}$ \\
\hline 75 & 5.4 & 2.1 & 6.1 & 6.3 & 7.3 & 3.9 \\
\hline 81 & 7.2 & 6.0 & 4.8 & 14.6 & 3.8 & 5.6 \\
\hline 89 & 6.7 & 4.5 & 5.0 & 8.1 & 2.1 & 5.4 \\
\hline $92-96$ & 8.9 & 4.2 & 5.8 & 1.3 & 1.1 & 3.7 \\
\hline $96-100$ & 22.9 & 13.7 & 8.9 & 1.1 & 2.2 & 6.7 \\
\hline $\operatorname{SEM}(\mathrm{n}=3)^{\mathrm{y}}$ & 5.23 & 1.63 & 3.41 & 2.83 & 3.42 & 3.41 \\
\hline Linear & $(P<0.10)$ & $(P<0.01)$ & $(P>0.10)$ & $(P<0.01)$ & $(P<0.10)$ & $(P>0.10)$ \\
\hline
\end{tabular}

${ }^{2} \mathrm{SCA}=5 \% \mathrm{CO}_{2}+3 \% \mathrm{O}_{2} ; \mathrm{LO}=0.5 \% \mathrm{CO}_{2}+1.0 \% \mathrm{O}_{2}$.

${ }^{y}$ Analysis of variance performed on percentages transformed to angles by $\sin ^{-1} \sqrt{P / 100}$. SEM values are in angles, but the means are back-transformed mean angles.

fruit held in SCA, low RH may reduce the incidence of senescent breakdown by increasing water and acetate ester loss, thereby decreasing tissue alcohol content (Wills, 1968). Senescent disorders were not observed in fruit stored in LO, which is consistent with previous reports (Lidster et al., 1985, 1987).

Low- $\mathrm{O}_{2}$ injury observed in LO-stored fruit, consisting of epidermal bluing and cortical browning, was found to decrease in fruit at higher storage RH (Table 3). Storage of apples in low RH may increase fruit resistance to $\mathrm{O}_{2}$ penetration into the tissue, especially from the LO-storage atmospheres, as evidenced by the increased resistance to ethane (Table 1). This effect may result in lower internal $\mathrm{O}_{2}$ levels in the fruit that could aggravate the development of LO injury as compared with similar fruit stored in higher RH.

The present study determined that 'McIntosh' apples in SCA and LO required different humidity control for optimal CA storage. High storage RH will result in the firmest fruit from either storage atmosphere. However, very high RH may increase the incidence of senescent disorders in 'McIntosh' fruit stored in SCA, which suggests that a lower RH, near $89 \%$ to $94 \%$, is best for SCA storage of 'McIntosh' apples. Fruit stored in LO at low RH (75\% to $89 \%)$ were found to be less firm and more susceptible to low- $\mathrm{O}_{2}$ injuries. Relative humidity of $96 \%$ to $100 \%$ proved beneficial for 'McIntosh' apples stored in LO. The benefits of storage humidity manipulation were not at the expense of losses due to decay (Table 3). Although these losses were variable over crop years, they were unaffected by storage atmosphere and humidity levels.

\section{Literature Cited}

Blanpied, G.D. 1981. A relationship between water loss and storage breakdown of 'McIntosh' apples. HortScience 16:525-526.

Cameron, A.C. and S.F. Yang. 1982. A simple method for the determination of resistance to gas diffusion in plant organs. Plant Physiol. 70:21-23.

Johnson, D.S. 1976. Influence of water loss on the storage quality of apples. Chem. \& Ind. 24:1044-1046.

Lau, O.L., R. Yastremski, and M. Meheriuk. 1987. Influence of maturity, storage procedure, temperature, and oxygen concentration on quality and disorders of 'McIntosh' apples. J. Amer. Soc. Hort. Sci. 112:93-99.
Lentz, C.P. and E.A. Rooke. 1964. Rates of moisture loss of apples under refrigerated storage conditions. Food Technol. 18:119-121.

Lidster, P.D., K.B. McRae, and E.M. Johnston. 1985. Retention of apple quality in low-oxygen storage followed by standard controlled atmosphere regimens. J. Amer. Soc. Hort. Sci. 110:755-759.

Lidster, P.D., E.C. Lougheed, and K.B. McRae. 1987. Effects of sequential low-oxygen and standard controlled atmosphere storage regimens on apple quality. J. Amer. Soc. Hort. Sci. 112:787-793.

Martin, D., T.L. Lewis, and J. Cerny. 1967. Nitrogen metabolism during storage in relation to breakdown of apples: I. Changes in protein nitrogen level in relation to incidence. Austral. J. Agr. Res. 18:271-278.

Porritt, S.W. and M. Meheriuk. 1973. Influence of storage humidity and temperature on breakdown in Spartan apples. Can. J. Plant Sci. 53:597-599.

Rasmussen, P.M. 1963. The influence of storage humidity on keeping quality of fruit. Tidsskr. Planteavl. 66:862-878.

Rockland, L.B. 1960. Saturated salt solutions for static control of relative humidity between $5-40^{\circ} \mathrm{C}$. Anal. Chem. 1375-1376.

Scott, K.J., G.E. Hall, E.A. Roberts, and R.B. Wills. 1964. Some effects of the composition of the storage atmosphere on the behavior of apples stored in polyethylene bags. Austral. J. Expt. Agr. \& Anim. Hush. 4:253-259.

Scott, K.J. and E.A. Roberts. 1967. Breakdown in Jonathan and Delicious apples in relation to weight loss during cool storage. Austral. J. Expt. Agr. \& Anim. Hush. 7:87-90.

Scott, K.J. and E.A. Roberts. 1968. The importance of weight loss in reducing breakdown of Jonathan apples. Austral. J. Expt. Agr. \& Anim. Hush. 8:377-379.

Smith, W.H. 1958. Reduction of low temperature injury to stored apples by modulation of environmental conditions. Nature (London) 181:275.

Smock, R.M. 1977. Nomenclature for internal storage disorders of apples. HortScience 12:306-308.

Trout, S.A., G.B. Tindale, and F.E. Huelin. 1940. Investigations on the storage of Jonathan apples grown in Victoria. C.S.I.R., Australia. Bul. 135.

Wilkinson, B.G. 1965. Some effects of storage under different conditions of humidity on the physical properties of apples. J. Hort. Sci. 40:58-65.

Wilkinson, B.G. 1970. The effect of evaporation on storage disorders of apples. Rept, E. Mailing Sta. 1969. p. 125-127.

Wills, R.B.H. 1968. Influence of water loss on the loss of volatiles by apples. J. Sci. Food Agr. 19:354-356. 